\title{
Agri-Tech Start-Ups: Using TCOP's to Enhance Growth in the UK and Vietnam
}

\author{
CHRISTOPHER J. Brown ${ }^{1}$, Nguyen Thuc Huong GIANG*, Nguyen Thi Thu THUY² \\ ${ }^{1}$ University of Hertfordshire \\ ${ }^{2}$ School of Economics and Management, Hanoi University of Science and Technology \\ *Corresponding author: giang.nguyenthuchuong@ hust.edu.vn
}

\begin{abstract}
Research purpose:

The research aims to understand how agritech startups in UK and Vietnam are using temporal Communities of Practice to tackle the challenges of business model changes to enhance their growth, and what their expectations on the benefits of this Communities of Practice in the short-term and long-term.
\end{abstract}

\section{Research motivation:}

With the increasing importance of the Agri-tech sector in helping the UK and Vietnam green economies both to grow, and to tackle the key challenges of self-sufficiency and sustainability, what role can the Communities of Practice play in supporting the Agri-tech start-ups? This study on the effectiveness of these temporal Communities of Practice, is paramount to support both the growth and sustainability of the two countries' Agri-tech sector and its link to a green economy.

\section{Research design, approach and method:}

The research takes a case study approach, using meetings, interviews, and other documentary data to capture the events, actions and changes of attitudes, behaviors and expectations of 8 Agritech start-ups (including 6 in UK and 2 in Vietnam) towards their use of temporal Communities of Practice.

\section{Main findings:}

The preliminary findings indicate a significant change in the level of trust and identity from the startups participating in the temporal Communities of Practice. Some of them quickly move into a value creation phase by which both quick-wins and medium-term actions generating financial \& non-financial business value. These Agri-tech enterprises are often attempting to exploit their existing business models, whilst at the same time explore a portfolio of new business opportunities that could generate new growth engines.

\section{Practical implications:}

The study may be helpful for policy makers and other practitioners, who are looking to develop and build these types of interventions that can take our insights into the fundamental actors, relations, and value exchanges within these temporal Communities of Practice. Businesses in other fields can also better understand the value and potential of tCOPs and apply this to their own sector.

Keywords: Agri-tech, Start-up, Networking, Knowledge transfer, Communities of Practice. 


\section{INTRODUCTION}

Agri-tech start-ups face several challenges in transitioning from the laboratory into the commercial marketplace.

The UK Government is keen to support innovation in this area, and have funded the development of four Agri-tech Centres (Innovate UK, 2021). In fact across Europe, Agri-tech start-ups have received funding for over $\$ 3.4$ billion, a $70 \%$ growth on the previous year (AgFunder Network Partners, 2020). The UK has a unique macro-environment for agriculture, and therefore is an attractive place to develop and commercialise Agri-tech innovation, over $70 \%$ of the UK land is dedicated to agriculture (Great Britain \& Northern Ireland, 2021). In 2017, Defra estimated that the Greenhouse Gas Emission (GHG) in 2017 were estimated to be $42.1 \%$ lower than they were in 1990 (Department for Business Energy \& Industrial Strategy, 2019). The UK government is keen to continue its investment in Agri-tech, seeing it as playing a major role in inspiring new diversity of green technologies in the UK farming sector. The challenges of Brexit and the on-going Pandemic have exposed the broader issues impacting on the UK farming sector, with its reliance on foreign workers and a general migration of labour away from the agriculture sector.

In Vietnam, agriculture and agri-businesses are among the key economic sectors, accounting for $14.85 \%$ of the country's GDP in 2020 and $39.45 \%$ of the total employment in the country. With the growing Agri-tech trends, the creation of more innovative tools by Agri-tech start-ups have been expected to sustain food security in Vietnam and significantly contribute to the country's development. Agri-tech start-ups in Vietnam face numerous challenges, including climate and adverse weather risks, market dynamics, unsustainable production methods, lack of a talented workforce, business training, funding, lack of scale, and slow regulatory reforms. Most of the challenges are like those facing the UK's Agri-tech start-ups. Agri-tech start-ups in Vietnam respond to the challenges by developing environmentally friendly, affordable, and easy-to-integrate solutions. They also seek help from CoPs which have proven increasing important role recently in startups access digital transformation (Nnamdi O. Madichie, Bolat, \& Taura, 2021). CoP is also known as a strategic tool to help manage knowledge, expertise and practice between collaborative members, and some forms of $\mathrm{CoP}$ have been established contributing the proliferation of knowledge, experience and skills to help members adapt to the fast-changing business environment, especially those driven by Universities (De-Graft Johnson Dei \& Walt, 2020).

However, research on those CoPs is still limited. While learning has long been established as one of the core values in the Vietnamese family and culture, its reflections in rural $\mathrm{CoP}$ in adapting to change have been largely overlooked in most of the studies of adaptation and rural development (Tran et al., 2018). It is worth noting that along with studies of CoPs in fields like education, computer science, healthcare, agricultural context remains an interest of research since this sector theoretically represents many typical aspects of CoPs. In practice, although CoPs may benefit agricultural business of all types, the CoPs, thanks to their dynamic and collective manner, can promote Agritech start-ups in a special way which requires further research for both UK and Vietnam.

UK and Vietnamese farmers are therefore seeking the support from CoPs to help boost overall productivity levels and competitiveness.

Research studies evaluating the limited uptake of 'greening business processes and overall business models', especially in the Agri-tech start-ups, has suggested two primary reasons:

1. the relatively limited dissemination of learning experiences from either being involved in pilot studies, or other business start-up workshops.

2. the apparent failure of business support services to influence deeper responses from the targeted Agri-tech start-up's, helping change their business model.

The problem is generic across all sectors driving, it revolves around knowledge exchange between knowledge hubs, those parties who regularly create and develop new knowledge (technologies, knowhow and processes), and the enterprises that have significant experience of marketplace needs and wants, in our Agri-tech cases. Increasingly UK \& Vietnamese governments are supporting schemes to provide this level of technology and knowledge exchange with both startups and scaleups. Global governments are increasing calling on their universities a research bodies to share their knowledge, expertise and practices with these startups in the form of 'temporal' communities of practice, in the case of the UK Agritech sector we explore the initiative of this collaboration co-funded by the French central bank. For the Vietnamese cases, we chose 2 startups in 2 different locations which have collaboration with several CoPs (one also has collaboration with universities) to see the similar and different points in comparision to the UK Agritech startup cases.

In overall, this study looks at: (1) the principal challenges facing Agri-tech start-ups in transitioning their novel products and services into the marketplace in both the UK and Vietnam, and (2) the impact of tCoP to Agri-tech start-ups in delivering knowledge and practical experience of transitioning these laboratory-based innovations, and limited pilot-tested products/services, into the marketplace and changing their business model to reflect market needs. We explore the issues and challenges of knowledge exchange, through these 
informal CoP's, by investigating existing empirical research on the challenges that these Agri-tech startups face in commercialising their products and services, by using case studies.

\section{KNOWLEDGE EXCHANGE AND TEMPORAL COMMUNITIES OF PRACTICE NEEDS}

At the beginning of this research paper, the authors suggested that the principal driver for Agri-tech start-ups to commercialise their technology through innovative business models, has created an opportunity to help drive climate change mitigation strategies in both the UK and Vietnam economies. Equally as important, are the opportunities that arise from these enterprises and consumers' demand for low carbon and sustainable products and services, representing opportunities to new start-ups and existing enterprises. Not forgetting, the importance of the strengthening and diversifying local and regional economies, which helps build low-carbon infrastructures and overall productive capacity, important ingredients in supporting successful knowledge exchange (BERR, 2010).

At the heart of the challenges and issues associated with sustainable development is the drive towards a low-carbon economy, and the impact this has on a enterprises' business model. How will these enterprises and the business entrepreneurs gain access to important knowledge and technology to support this transition? The future success of Agritech start-ups and entrepreneurs to unlock the talent, knowledge and skills held in these knowledge portals, will largely depend on their ability and motivation to engage with them. Research in the public-private science interaction (Cockburn \& Henderson, 1998) suggests that absorptive capacity of these enterprises is important, but equally so is the encouragement and reward given to staff to actively engage with these public sector knowledge portals. Knowledge portals or knowledge hubs are often a combination of government, sector or knowledge institutes that have the responsibility to facilitate and speed-up the diffusion of innovative knowledge to the business and research community (van Baalen, Bloemhof-Ruwaard, \& van Heck, 2005). Entrepreneurs, intrapreneurs and innovators have always used outside professional and business networks to gain access to important knowledge and skills essential to their respective roles and responsibilities in driving innovation.

Since people are the most important conduits of information on knowledge and experience, then allowing employees sufficient time to codify these areas is essential. These knowledge workers are five times more likely to turn to another person, for such information, either inside or outside the organization, than to any formal database or $\mathrm{KM}$ system (Cross \& Parker, 2004). These learning activities whereby people engage in tacit-tacit, and explicit-explicit, knowledge-sharing are an essential part of building social capital (Cohen \& Prusak, 2001) and CoPs. Increasingly, such one-to-one organisational knowledge exchanges are hard to maintain in their traditional form, such as informal hall talks and coffee area small talk (Garavan, Carbery, \& Murphy, 2007), because people may not be in close proximity to one another, or they work in small enterprises. Interestingly communities are still created, whereby partners exchange knowledge $\&$ experience both within the organization and outside it. Yet there is little research that studies the dynamics of these community partners when the stakeholders are from very diverse backgrounds, such as private and public sectors. Universityenterprise collaborative CoPs are special cases of CoP's where the initial intention is set up the community to service the needs of the project and the entrepreneurs running the enterprises.

Yet, at the heart of enterprises' search for external knowledge, is the approach they take in identifying appropriate knowledge sources and the depth of knowledge available. This identification of external knowledge sources is linked very closely to previous methods of obtaining knowledge/technology: informal networking with public and private entities, R\&D collaboration and specific technology acquisition (Kang \& Kang, 2009). Knowledge exchange is a critical tool or activity in sustaining an enterprise. Who are these knowledge hubs and what role do they play in creating value in the knowledge exchange activity?

\subsection{Community of Practice and Knowledge Exchange}

Knowledge exchange has depended over the years on specific intermediaries to bring together global scientific knowledge and embryonic technologies and present these to enterprises who can best develop viable product and services. These intermediaries help generate specific know-how and importantly conduct some of the early-stage development of product concepts (Yusuf, 2008).

Formally, communities of practice are "groups of people who share a concern or a passion for something they do and learn how to do it better as they interact regularly." Communities of Practice (CoP) are often formed and maintained by "a group of people having a common identity, professional interests and that undertake to share, participate and establish a fellowship" (Dalkir, 2005). These communities differ from other types of networks, such as "project teams", "cross-functional teams" and other inter-organizational teams (Probst \& Borzillo, 2008) in that the roles of partners are not formally assigned or specific to one task. Secondly, the community value is measured by the quantity and quality of the exchanges of knowledge, experience, and skills. The authors assert that CoP's are usually expected to persist and grow, long after the initial rationale for the community has been reached. In fact, CoPs can be long-standing or transitory. They are frequently created for a specific 
purpose, such as the sharing of knowledge in respect of a specific area, thereby enhancing all parties' learning, and co-creating a value for this community from such sharing (Adams \& Freeman, 2000; Seufert, Krogh, \& Bach, 1999). This shared value is based on both knowledge in action of the partners (see below for a formal definition) and the formal propositional knowledge presented by the individuals to the community, during its life cycle.

Beside common CoPs, there is also a kind of CoPs between Universities/Research Institutes and Agritech start-ups which are the unique communities bringing together partners that would not normally share the same formal professional affiliations, or informal enterprise support networks. Effectively CoP's are often a special outcome of entrepreneurial eco-systems, and we are evaluating the conditions that make these ecosystems-CoP's more or less favorable for entrepreneurship/startup activity. Yet they exhibit many of the basic characteristics or traits associated with general CoPs: a common goal (or joint enterprise), mutual engagement (overall commitment) and a shared repertoire (interest in finding solutions to enterprise challenges), see figure 1 below:

\section{Temporary CoP Characteristics}

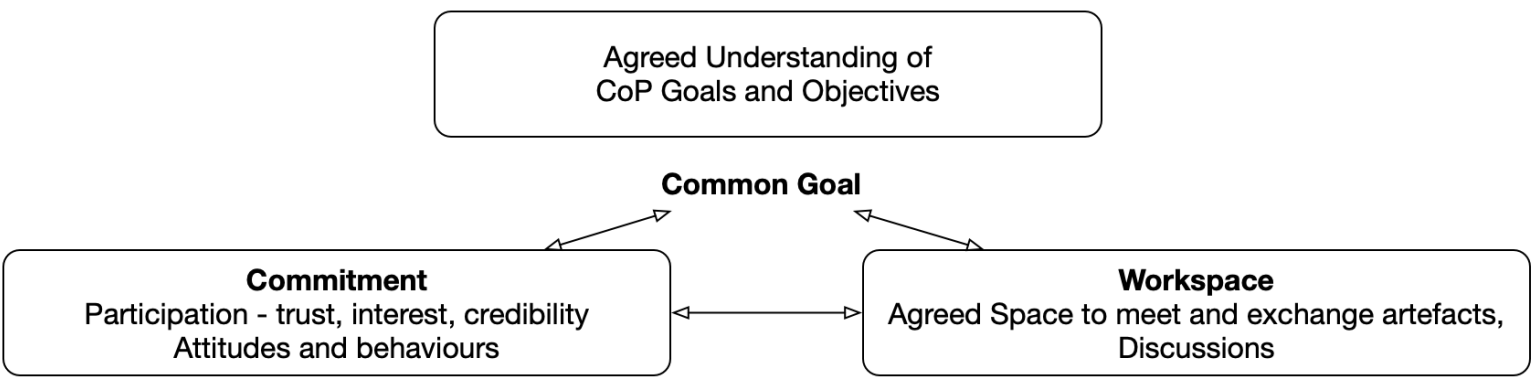

Fig. 1. Characteristics of temporal CoPs (adapted from Wenger, 1997)

The tCoP life cycle is built upon the continuous process of learning and reflection of the CoP members.

\subsection{Entrepreneurial Strategic Orientation, Business Model Innovation and CoPs needs}

Entrepreneurial strategic orientation can be considered as the principles regarding risk-taking, reform, innovation, and the competition that guide and influence enterprise activities and produces behaviours that ensure enterprise survival and performance (Gatignon and Xuereb, 1997).

Research in the 70's suggested that problems in enterprises are most often rooted in past decisions rather than any present marketplace dynamics or events (Aragon-Sanchez \& Sanchez-Maron, 2005; Greiner, 1998; Miles \& Snow, 1978). Research by Miles and Snow presented a typology that linked strategic orientation to those enterprises' evaluation of internal and external environmental factors or drivers, and that these triggered changes in their strategic orientations - management style, structural, cultural and process orientated. The research suggested that these strategic orientations result from the business entrepreneurs' and the enterprises' analysis of internal and external environmental factors (competitiveness, marketplace uncertainty and ambiguity, market orientation, economic growth), and reflect their values, attitudes and practices towards ecologically driven innovation:

Defenders these enterprises often focused on a narrow or limited product market, creating a niche for themselves where they have subsequently developed a leading position. These enterprises fall into a strategy of trying to protect their market share and revenues/profits.;

Prospectors these enterprises often start with a single successful product, but then steadily grow their product/service portfolio by their continuous search for new market opportunities by applying their knowledge and know-how to innovate and develop superior customer-valued products and services.

Analyzers these enterprises can act both, defensively, or prospectively, depending on their analysis of the environmental challenges and the perceived innovationresources that would be required.

Reactors these enterprises are characterized by perpetual instability and inconsistency in their strategies, predominantly because of their incapacity to respond effectively environmental changes. 
Communities of practice can effectively support and enhance the company's strategic capabilities thanks to the nature of collective learning, knowledge creation and sharing of CoPs. Indeed, knowledge strategy an integral part of the company's overall strategy, which is intended to lead a company through changes and shifts, securing its future growth and sustained success. Therefore, companies based on determined entrepreneurial strategic orientations need to understand what knowledge will result in commercial success. They need to keep this knowledge on the cutting edge, deploy it, leverage it in operations and spread it across the organization to generate capabilities (Teece, 2010). Wenger et al. (2002) argue that using CoP in the strategic context is a practical way to manage knowledge as an asset systematically, just as companies manage other critical assets. CoPs can help companies develop new strategies complementing existing ones, realize a business strategy, and go beyond that change the company's business model.

Business model and business strategy have a close relationship, forming two essential preconditions and fundamentals of a company existence. A business model is an outline of how a company plans to make money with its product and customer base in a specific market. A business strategy describes and explains how, where and for what purpose and goal a business model will be used. Businesses are constantly managing a portfolio of both new and existing business models, that exploit and explore business/market opportunities. Utilizing both internal and external resources and expertise to both exploit and improve their existing business model, whilst simultaneously exploring new business models that will become their future growth engines to both disrupt and protect against disruption in their market (Osterwalder, Pigneur, Smith, \& Etiemble, 2020). Companies change their business model to fit business operations within specific prevailing business environments, to identify and explore growth opportunities, with the aim of creating sustainable competitive advantages (Müller 2014). CoPs possibly support companies in capturing the changes of business environment and adapt their business model for successful strategy and better growth. It is worth noticing that benefits from CoPs varies with types and development phases of enterprises. Companies needs to identify the potential CoPs that will effectively nurture their entrepreneurial strategy and business model.

\section{RESEARCH METHODOLOGY}

With the research study being focused around the perspective of the business entrepreneurs, it is important to embrace a research approach that "researchers need to develop the capacity to see their topic with new and different lenses in order to look beyond and transform their own knowledge" (Peter Clough \& Nutbrown, 2012). It is for this reason that the authors choose a qualitative approach to utilize interviews and observations to explore the understanding of our business entrepreneurs. To explore the business entrepreneurs' sensemaking of the knowledge and expertise exchange we adopted an interpretative epistemology and thus feel confident that we could "understand the world from the perspective of the participants in that world" (Peter Clough \& Nutbrown, 2012). We are therefore adopting an inductive approach to the development of theory building, and therefore follow a traditional social constructionist interpretative methodology (Mark Saunders, Lewis, \& Thornhill, 2019), in terms of data collection and content analysis.

\section{a. Method}

The research design takes a case study approach, being the best approach when 'How' and 'Why' questions are the objective of the study (Mark Saunders et al., 2019). Clearly, a case study approach generates an 'In-depth' understanding of the social phenomenon under-study and focuses on the contemporary events and activities influencing our study participants and their businesses.

Of course, using a case study approach provides a "unique strength is its ability to deal with a variety of evidence...documents, artefacts, interviews and observations... Beyond what might be available in a conventional historical study" (Robert K. Yin, 2018). Other researchers talk about the caution a researcher should have to using a case study approach, highlighting the difficulty of generalisations of the findings (Lara Carminati, 2018). Yet using multiple cases will "increase the commonality or variety of interpretations that they produce providing a greater claim of generalisability" (Lara Carminati, 2018).

\section{b. Research Questions}

Our research aim is to study the use and the impact of temporal Communities of Practice (tCoP) on Agritech start-ups in accessing knowledge and expertise key to their growth. We have broken this down into three primary research questions:

- How is their current business model challenged by the lack of knowledge and expertise?

- What do they perceive are the main benefits of seeking expertise and knowledge from the tCoP?

- What are their expectations on the benefits that these temporal Communities of Practice (tCoP) can bring to meet their short-to long-term needs?

\section{c. Data Collection}

Though it would be interesting to approach our data collection as a state of tabula rasa or as a blank slate (Glaser \& Strauss, 1967). It is logical to accept that the researcher in these case studies has some prior knowledge, and that before we committed to this 
field work, we undertook an extensive literature review around the topics of communities of practice, knowledge exchange and business entrepreneur's mindsets toward seeking knowledge and expertise. Data was collected from October 2020 to September 2021 in both UK and Vietnam, with 6 agritech startups in UK and 2 Agritech Startups in Vietnam, to better understanding the difference of companies in 2 countries in perceiving the benefits and the needs of CoP to their business operations.

\section{d. Six Agritech Startups Case Study}

As previously stated, the UK and Vietnamese governments are increasingly focusing on the need to support start-ups in many of the key sectors responsible for increasing productivity, growth and contributing to the switch towards a green economy. The authors have chosen the 6 cases within a govermental supported program called the Climate Change Initiative Programme. Table 1 provides some background information about the 6 UK cases' operations and characteristics.

Table 1. - UK Agritech Start-up Case Studies

\begin{tabular}{ccc}
\hline Firm Characteristics & Strategy & Market Dynamics \\
\hline A & Producing Chitin film & Setting up a biorefinery \\
\hline B & Compositable Plant Pots from Alpaca manure & Open the Market direct to Farmer \\
\hline C & Drone imagery to save time and money & Current Pilot Study in Malaysia \\
\hline D & Aquaponics to accelerated Tree Growth & Small Demo in Construction \\
\hline E & Soil Health Intelligence & Agronomists and Farm-managers \\
\hline F & Plant-based Proteins & Plant-based Food Protein markets
\end{tabular}

We also interviewed the founders of the 2 Agritech startups in Vietnam. Table 2 provides some general information about their activities.

Table 2. - Vietnamese Agritech Start-up Case Studies

\begin{tabular}{clc}
\hline $\begin{array}{c}\text { Firm } \\
\text { Characteristics }\end{array}$ & \multicolumn{1}{c}{ Strategy } & Market Dynamics \\
\hline $\mathrm{G}$ & \multicolumn{1}{c}{ Producing Fresh Vegetable } & $\begin{array}{c}\text { Using hydroponics and automatic environment } \\
\text { control system }\end{array}$ \\
\hline $\mathrm{H}$ & $\begin{array}{l}\text { Providing services and products for the seafood } \\
\text { industry. }\end{array}$ & \begin{tabular}{c} 
Organic agriculture with high technology \\
\hline
\end{tabular} \\
\hline
\end{tabular}

\section{ANALYSIS AND KEY FINDINGS}

The findings are presented in the form of the eight enterprise case studies, extracts are provided of the entrepreneur, intrapreneur, and academic perspectives. Though in all cases the academic and intrapreneurs values, attitudes, and practices and therefore their strategic orientations coincided.

\section{e. UK Agritech Start-ups}

\section{a. Agritech start-up A}

This enterprise operates in the Agritech sector, providing products and services to the bioplastics industry.

Table 3. - Agritech Start-up informal tCoP, Overall Entrepreneurial Intentions (Started ${ }^{1}$ and Finished $^{2}$ )

\begin{tabular}{|c|c|c|c|c|}
\hline $\begin{array}{l}\text { Perceptions of the } \\
\text { need for Business } \\
\text { Model change }\end{array}$ & Key Challenges & $\begin{array}{l}\text { Key Business } \\
\text { Model Changes }\end{array}$ & $\begin{array}{c}\text { Change in EI } \\
\text { Values, Attitudes } \\
\text { and Practices }\end{array}$ & $\begin{array}{c}\text { Expected and } \\
\text { Actual Impact } \\
\text { (Performance } \\
\text { Measure) } \\
\end{array}$ \\
\hline $\begin{array}{r}\text { Enterprise A } \\
\text { Entrepreneurial } \\
\text { Intentions - the very } \\
\text { start of their Business }\end{array}$ & $\begin{array}{l}\text { Predicted } 16 \% \\
\text { growth rates in the } \\
\text { bioplastic field are } \\
\text { encouraging strong } \\
\text { competition }^{1}\end{array}$ & $\begin{array}{l}\text { Develop new } \\
\text { markets }\end{array}$ & Reactive $^{1}$ & $\begin{array}{l}\text { Early Success in } \\
\text { attracting } \\
\text { investment }^{1}\end{array}$ \\
\hline $\begin{array}{r}\text { Model - looking for } \\
\text { exemplars in the } \\
\text { sector }\end{array}$ & $\begin{array}{l}\text { How to engage } \\
\text { with these new } \\
\text { Bioplastic } \\
\text { customers }^{2}\end{array}$ & $\begin{array}{l}\text { Marketing best } \\
\text { practice to existing } \\
\text { markets }^{2}\end{array}$ & Analyzer $^{2}$ & $\begin{array}{l}\text { First life cycle } \\
\text { testing of the } \\
\text { product and its } \\
\text { quality }^{2}\end{array}$ \\
\hline
\end{tabular}


Target Customer Segments - The start-up has identified that the plastics market has very a pronounced growth rate, particularly in the bioplastics area, the global market of which was worth over $\$ 8.3$ billion in 2019 . This largely driven by the increased demand for bioplastics in the packaging sector, which is particularly interested in the biodegradable or compostable bioplastics, which have the added advantages of reducing carbon footprint, and being a generally eco-friendly disposable solution and recyclable. Chitin as a completely biomaterial is compostable, bio-based, and eco-friendly material with antibacterial, nontoxic and hydrophobic properties. Traditional petrol-based polymer plastics have the advantages of being durable, versatile, and cheap, take about 400 years to degrade in normal environmental conditions.
Value Propositions - The start-up is in the early stages of proof-of-concept, as such need to establish a pilot plant to prove the following:

- Develop an initial insert colony, feeding these insects on organic waste.

- Extract the chitin from the insect's exoskeletons.

- Develop the production of bioplastics from this chitin, and test the underlying properties

Channels - In linking the chitin farming to the production and manufacturing of bioplastics, there are many issues around the channels to the market to both test and develop.

Relationship Management - early stages of the proof-of-concept stage, so the main value of the programme is the access to both resources of the university/research institutes and their expertise in the different elements of the production process.

Table 4. - Agritech Start-up informal tCoP, looking at the Frontstage of the Business Model (Started ${ }^{1}$ and $^{-}$ Finished $^{2}$ )

\begin{tabular}{|c|c|c|c|}
\hline $\begin{array}{l}\text { Perceptions of the } \\
\text { need for Business } \\
\text { Model change } \\
\end{array}$ & Key Challenges & Community of Practice Needs & $\begin{array}{l}\text { Temporal CoP - } \\
\text { achievements }\end{array}$ \\
\hline Customer Segment & $\begin{array}{l}\text { Identifying the Market } \\
\text { Potential - Initial Sales } \\
\text { Forecast }^{1}\end{array}$ & $\begin{array}{l}\text { Market intelligence and Insight } \\
\text { Expertise (Understanding of the } \\
\text { marketplace) }\end{array}$ & $\begin{array}{l}\text { Expect to commission this } \\
\text { MI\&S report in the next six } \\
\text { months }\end{array}$ \\
\hline \multirow[t]{2}{*}{ Value Proposition } & $\begin{array}{l}\text { Larval Production } \\
\text { Chitin Extraction } \\
\text { Purity of the product } \\
\text { Scale-up } \\
\text { Market Testing }\end{array}$ & $\begin{array}{l}\text { Proof of concept - the first full- } \\
\text { scale run through of the } \\
\text { production process - resulting in } \\
\text { a bio-gradable bioplastic. }\end{array}$ & $\begin{array}{l}\text { Expertise and mentoring from } \\
\text { the CoP. }\end{array}$ \\
\hline & $\begin{array}{l}\text { Lab Suppliers - use of } \\
\text { Chitin for Pharma } \\
\text { Polymer and Resin } \\
\text { Extruders } \\
\text { Biodegradable Film } \\
\text { Producers }\end{array}$ & $\begin{array}{l}\text { Developing at expert CoP with } \\
\text { understanding of polymer } \\
\text { extruders, consumer brands, and } \\
\text { UK retailers. }\end{array}$ & $\begin{array}{l}\text { Mentoring and coaching from } \\
\text { the CoP }\end{array}$ \\
\hline $\begin{array}{l}\text { Relationship } \\
\text { Management }\end{array}$ & $\begin{array}{l}\text { Comparison of the life } \\
\text { cycle of the Bioplastic } \\
\text { production against } \\
\text { traditional petrol-based } \\
\text { plastic production. }\end{array}$ & $\begin{array}{l}\text { Production of a comparison } \\
\text { report that will be used for sales } \\
\text { collateral. }\end{array}$ & $\begin{array}{l}\text { Mentoring and coaching from } \\
\text { the CoP }\end{array}$ \\
\hline
\end{tabular}

\section{b. Agritech Start-up B}

Enterprise B has the goal of giving the UK's alpaca farmer community the opportunity to add further revenue streams to its operations.

Table 5. - Agritech Start-up informal CoP, Strategic Orientation and Business Model Changes (Started ${ }^{1}$ and Finished ${ }^{2}$ )

\begin{tabular}{ccccc}
\hline $\begin{array}{c}\text { Perceptions of the need } \\
\text { for Business Model } \\
\text { change }\end{array}$ & Key Challenges & $\begin{array}{c}\text { Key Business } \\
\text { Model Changes }\end{array}$ & $\begin{array}{c}\text { Change in Values, } \\
\text { Attitudes and } \\
\text { Practices }\end{array}$ & $\begin{array}{c}\text { Expected and } \\
\text { Actual Impact } \\
\text { (Performance } \\
\text { Measure) }\end{array}$ \\
\hline Enterprise B & $\begin{array}{c}\text { Bringing a new } \\
\text { product to } \\
\text { market }^{1}\end{array}$ & $\begin{array}{c}\text { Develop new } \\
\text { markets and } \\
\text { increase share of } \\
\text { existing market }\end{array}$ & Analyser ${ }^{1}$ & $\begin{array}{c}\text { Quick solutions to } \\
\text { market }\end{array}$ \\
$\begin{array}{c}\text { Entrepreneurial } \\
\text { Intentions - bringing } \\
\text { precision Agri-tech }\end{array}$ & & $\begin{array}{c}\text { identification and } \\
\text { sales output } \\
\text { options }\end{array}$ \\
\hline
\end{tabular}




\begin{tabular}{rccc}
$\begin{array}{r}\text { solution to over 50,000 } \\
\text { farmer sector, cheap, } \\
\text { easy-to-use and practical }\end{array}$ & $\begin{array}{c}\text { Expand the cost- } \\
\text { effective business } \\
\text { model of Alpaca } \\
\text { farmers }\end{array}$ & $\begin{array}{c}\text { Develop the } \\
\text { business model } \\
\text { ROI for Alpaca } \\
\text { farmers }\end{array}$ & $\begin{array}{c}\text { Prospector }{ }^{2} \\
\text { fully-field tested } \\
\text { products, and } \\
\text { developed sales } \\
\text { tools for }\end{array}$ \\
$\begin{array}{c}\text { commercialization } \\
\text { of two of the main } \\
\text { product lines }\end{array}$ \\
\hline
\end{tabular}

Key Target Customers - 1500 Alpaca farmers distributed around the UK, generating over 92 tonnes of nutrient rich manure per day, they all have a manure management issue. Current need is to dispose of this manure, with the opportunity to generate an additional revenue stream, with the net benefits of solving their manure management challenge and supplying the horticultural market with an additional product. For the sector, the longterm issues around GHG production on the composting of the manure on the land are obvious. A long-term solution is both desirable from the sectors perspective and from the individual farmer wanting a solution that offers an addition revenue stream.

Value Propositions - Enterprise B's product provides a more convenient local process to convert the bi-product into a rich compostable product desired by the horticultural sector. Enterprise B have worked with an Asian manufacturer to produce a cost-effective organic fertiliser converter, that can either be bought or leased by the farmer. A new opportunity came in the first few months of the business collaboration with this funding stream, utilising the product with a process that use captured $\mathrm{CO}_{2}$, and Ammonia will create a product that has substantially more benefits for both soil conditioning and the reduction of $\mathrm{CO}_{2}$ and Ammonia into the atmosphere. The composter plant output is a product that has a $70 \%$ reduced mass for the farmer, and a product that be more easily transported and then converted into a nutrient rich biochar than can be returned to help support a healthy soil regeneration both in the agriculture and horticulture sectors.

Channels to Market - The challenge for the business has not been the general proof of concept or the application of the technology, the business had already conducted extensive field-trials using the new plant to convert the raw Alpaca manure and producing the performance/operational metrics that would be essential for proving the ROI for any Alpaca farmer using the technology. No, the real challenge has been the scaling-up of the microbusiness, evaluating the opportunities to create more products that can scale-up the revenue streams to get the business onto a more sustainable footing.

Relationship Management - Finding funding streams is still an important need of the business, the opportunity to apply for this funding programme is key to them paying for IP filing. The challenge is getting knowledge and expertise around the development of a sustainable business model. Applying for this programme was the first that the business owner had applied for, feeling that it would give them access to the knowledge and expertise essential for their growth. Out of their initial meeting with one of the business advisor team, they have subsequently won a UKRI project with a university to help create their first B2C product, the result of which will be a product line bearing the businesses branding, and sold through nurseries and garden centres.

Table 6. - Agritech Start-up informal tCoP, looking at the Front-Stage of the Business Model (Started ${ }^{1}$ and $^{-}$ Finished $^{2}$ )

\begin{tabular}{|c|c|c|c|}
\hline $\begin{array}{l}\text { Perceptions of the } \\
\text { need for Business } \\
\text { Model change }\end{array}$ & Key Challenges & $\begin{array}{c}\text { Community of Practice } \\
\text { Needs }\end{array}$ & $\begin{array}{l}\text { Temporal CoP - } \\
\text { achievements }\end{array}$ \\
\hline Customer Segment & $\begin{array}{l}\text { Identified a B2C } \\
\text { opportunity to sell the } \\
\text { product repackaged for } \\
\text { sales directly to } \\
\text { consumer ........ }\end{array}$ & $\begin{array}{l}\text { Market intelligence and } \\
\text { Insight Expertise (Need to } \\
\text { understand the end-customers } \\
\text { attitudes and behaviors to } \\
\text { consuming this biodegradable } \\
\text { product) }\end{array}$ & $\begin{array}{l}\text { Looking Market } \\
\text { Intelligence and Insight } \\
\text { report for additional } \\
\text { markets for both the refined } \\
\text { and unrefined products. }\end{array}$ \\
\hline Value Proposition & $\begin{array}{l}\text { Over } 1500 \text { Alpaca } \\
\text { farmers in the UK, } \\
\text { Producing over } 92 \text { tons } \\
\text { a day of nutrient rich } \\
\text { manure. A new income } \\
\text { generator. }\end{array}$ & $\begin{array}{l}\text { Identifying opportunities for } \\
\text { additional revenue streams for } \\
\text { the UK's Alpaca farmers is } \\
\text { essential to selling Enterprise } \\
\text { B's solutions and developing } \\
\text { further opportunities.... }\end{array}$ & $\begin{array}{l}\text { Using the CoP members to } \\
\text { help identify further product } \\
\text { development opportunities. }\end{array}$ \\
\hline Channels & Commercial channels & Developing at expert CoP & Currently meeting some \\
\hline
\end{tabular}




\begin{tabular}{clll}
\hline & $\begin{array}{l}\text { through market garden } \\
\text { operators }\end{array}$ & $\begin{array}{l}\text { with understanding of } \\
\text { polymer extruders, consumer } \\
\text { brands, and UK retailers. }\end{array}$ & barriers in delivering theses. \\
\hline $\begin{array}{c}\text { Relationship } \\
\text { Management }\end{array}$ & $\begin{array}{l}\text { Looking at other R\&D } \\
\text { partners who could } \\
\text { develop further products } \\
\text { from this raw material. }\end{array}$ & $\begin{array}{l}\text { Working with the CoP } \\
\text { members to identify nascent } \\
\text { partners in this particular } \\
\text { field. }\end{array}$ & $\begin{array}{l}\text { Most useful network } \\
\text { partners and members that } \\
\text { have relevant contacts. }\end{array}$ \\
\hline
\end{tabular}

\section{c. Agritech Start-up C}

Enterprise $\mathrm{C}$ are committed to bringing the advantages of new agri-tech products to Joe Farmer. There main selling point is to bring precision agricultural management to the masses by making it cheap, easy-to-use and practical.

Table 7. - Agritech Start-up informal CoP, Strategic Orientation and Business Model Changes (Started ${ }^{1}$ and Finished ${ }^{2}$ )

\begin{tabular}{|c|c|c|c|c|}
\hline $\begin{array}{c}\text { Perceptions of the need } \\
\text { for Business Model } \\
\text { change }\end{array}$ & Key Challenges & $\begin{array}{c}\text { Key Business Model } \\
\text { Changes }\end{array}$ & $\begin{array}{c}\text { Change in Values, } \\
\text { Attitudes and } \\
\text { Practices }\end{array}$ & $\begin{array}{l}\text { Expected and } \\
\text { Actual Impact } \\
\text { (Performance } \\
\text { Measure) } \\
\end{array}$ \\
\hline $\begin{array}{l}\text { Enterprise C } \\
\text { Entrepreneurial Intentions }\end{array}$ & $\begin{array}{c}\text { Re-packaging } \\
\text { Satellite data is } \\
\text { being offered by } \\
\text { many } 1\end{array}$ & $\begin{array}{c}\text { Develop new markets } \\
\text { and increase share of } \\
\text { existing market }^{1}\end{array}$ & Analyser $^{1}$ & $\begin{array}{l}\text { Quick solutions to } \\
\text { market identification } \\
\text { and sales output } \\
\text { options }^{1}\end{array}$ \\
\hline $\begin{array}{r}\text { - Long sales cycles in } \\
\text { agriculture is always } \\
\text { challenging for start-ups }\end{array}$ & $\begin{array}{l}\text { Expand the cost- } \\
\text { effective business } \\
\text { model of Alpaca } \\
\text { farmers }^{2}\end{array}$ & $\begin{array}{c}\text { Develop the business } \\
\text { model ROI for } \\
\text { Alpaca farmers }{ }^{2}\end{array}$ & Prospector $^{2}$ & $\begin{array}{c}\text { Development of } \\
\text { fully-field tested } \\
\text { products, and } \\
\text { developed sales tools } \\
\text { for commercialization } \\
\text { of two of the main } \\
\text { product lines }\end{array}$ \\
\hline
\end{tabular}

Key Target Customers - Enterprise C's end users are farmers and growers, but their direct customers are the broader pipeline of product/services to the agricultural sector e.g. farmers/growers, agrochemical companies, agronomists and farm management companies. Across Europe their already a $£ 77$ billion overspend on pesticides, a significant spend for small to medium-sized farmers.

Value Propositions - Enterprise C's product provides an AI model that delivers acceptable information to help them make more informed decisions. What is different about Enterprise C's solution is that it uses free Satellite data combined with AI to offer truly affordable solutions to help framers/growers of all sizes reduce their reliance on harmful products and improve their profit margins. The Enterprise C's platform alerts farmers when stress has been detected and will diagnose crop disease using images taken from a smartphone, drone or rover.

Channels to Market - Competition in the marketplace is strong, with competitors offering farmers big technology and specifically to those farmers willing to spend big money on electronic gadgets. Their farmer clients want to help the environment, and by the use of Enterprise C's crop/soil management they can maximise the fields growing period and therefore reduce the impact that bare soil can have on the climate.

Relationship Management - The enterprise $\mathrm{C}$ has a working prototype that is keen to get more field data from working with the farmers/growers in the UK/Asia. They have a live project in Malaysia, their field client captures drone imagery of rice fields, Enterprise $\mathrm{C}$ analyses these photos and performs insert detection and creates a recommendation for the farmer/grower on the general health of the crop. The Malaysian government is monitoring the pilot and is to provide funding for further field-trials. Enterprise $\mathrm{C}$ is already ahead of the game in terms of powerful relationships with several governments and working with their agricultural departments on knowledge exchange. 
Table 8. - Agritech Start-up informal tCoP, looking at the Front-Stage of the Business Model (Started ${ }^{1}$ and $^{2}$ Finished $^{2}$ )

\begin{tabular}{|c|c|c|c|}
\hline $\begin{array}{l}\text { Perceptions of the } \\
\text { need for Business } \\
\text { Model change } \\
\end{array}$ & Key Challenges & $\begin{array}{c}\text { Community of Practice } \\
\text { Needs }\end{array}$ & $\begin{array}{l}\text { Temporal CoP - } \\
\text { achievements }\end{array}$ \\
\hline Customer Segment & $\begin{array}{l}\text { Delivering the } \\
\text { intelligence support } \\
\text { information important to } \\
\text { their client - the } \\
\text { farmer/grower ....... }\end{array}$ & $\begin{array}{l}\text { Developing a product that is } \\
\text { fit for both the Western } \\
\text { Countries and has application } \\
\text { in the third-world is very } \\
\text { important. We need tools to } \\
\text { allow us to evaluate these } \\
\text { different markets? }\end{array}$ & $\begin{array}{l}\text { We already have alive } \\
\text { project in Malaysia that is } \\
\text { helping rice farmers. }\end{array}$ \\
\hline \multirow[t]{2}{*}{ Value Proposition } & $\begin{array}{l}\text { For livestock farmers, } \\
\text { the more they can keep } \\
\text { their herd grass-fed this } \\
\text { has a much smaller } \\
\text { carbon footprint. }\end{array}$ & $\begin{array}{l}\text { Two products help deliver } \\
\text { both general information on } \\
\text { crop health and management, } \\
\text { whilst the other product is } \\
\text { focused on then the } \\
\text { application for sprayers ... }\end{array}$ & $\begin{array}{l}\text { We are keen to show and } \\
\text { prove the deliverables on } \\
\text { this product/service in both } \\
\text { carbon footprint and GHG } \\
\text { emission reductions. }\end{array}$ \\
\hline & $\begin{array}{l}\text { Some of this is through } \\
\text { our relationships with } \\
\text { Overseas governments } \\
\text { and agricultural } \\
\text { departments. }\end{array}$ & $\begin{array}{l}\text { Again, project management } \\
\text { tools to more accurately cost } \\
\text { the opportunity costs and } \\
\text { provide better AI } \\
\text { management of projects.. }\end{array}$ & $\begin{array}{l}\text { They are already using } \\
\text { these programmes } \\
\text { deliverables to help } \\
\text { influence government } \\
\text { policies. }\end{array}$ \\
\hline $\begin{array}{l}\text { Relationship } \\
\text { Management }\end{array}$ & $\begin{array}{l}\text { Developing a wider } \\
\text { network of } \\
\text { farmers/growers to } \\
\text { better understand the } \\
\text { key challenges that } \\
\text { affect the sustainability } \\
\text { of their farm/crop ... }\end{array}$ & $\begin{array}{l}\text { Extend the partnerships with } \\
\text { other state departments and } \\
\text { governments around the } \\
\text { world. }\end{array}$ & $\begin{array}{l}\text { Further develop the green } \\
\text { credentials of this land } \\
\text { management on the } \\
\text { reduction of pesticides in } \\
\text { the EU and worldwide. }\end{array}$ \\
\hline
\end{tabular}

\section{d. Agritech Start-up D}

Enterprise D has developed an agroforestry product that utilises a self-contained modular environmentally controlled chamber. This module utilises an aquaponics nutrition system, that accelerates the growth of trees, helping deliver a variety of high-value, high yield crops for local food production.

Table 9. - Agritech Start-up informal CoP, Strategic Orientation and Business Model Changes (Started ${ }^{1}$

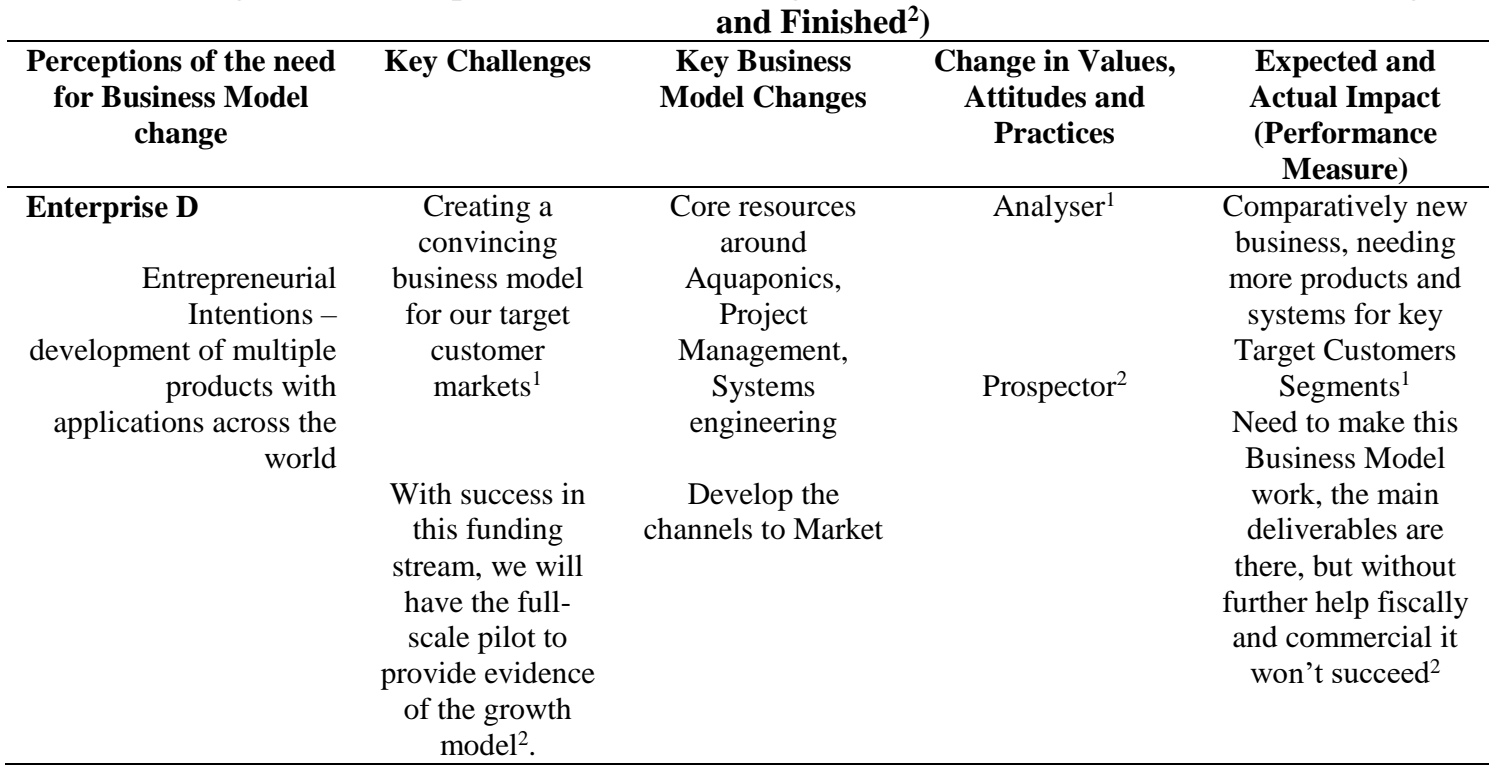

Key Target Customers - Targeted customers for this agroforestry modular system are small-large farmers, with a particular interest from local councils and county authorities, and community project funders.

Value Propositions - Enterprise D's core value proposition is that there is currently not another product like it on the marketplace, it offers an accelerated growth of trees and provides certifiable contributions to a positive impact on the climate crisis. The aquaponics nutrient delivered system approach proved maximum reduction of nitrogenbased fertilisers, thus minimising the impact on N2 emissions. Enterprise D has already built up a global-shared data service available to all its 
customers to help optimise growing conditions in whatever environmental conditions, the community of practice allows optimal shared advice, knowledge and experience on successes and failures. The system is deployable and re-deployable to different locations depending on the crop.

Channels to Market - Competition in the marketplace is strong, with traditional polytunnel manufacturers and channels being the obvious channel for farmers to source their capital equipment. We have applied for this funding to help us construct full-scale pilot system that will enable us to conduct systematic growth trials, and with this understand exactly what the business model would be for each type of crop.

Relationship Management - Enterprise D are still in the early stage of pilot testing. There is little that is on the website at the moment, this has got to be a priority for us, as this is the window into what our enterprise

offers.

Table 10. - Agritech Start-up informal tCoP, looking at the Front-Stage of the Business Model (Started ${ }^{1}$ and Finished ${ }^{2}$ )

\begin{tabular}{|c|c|c|c|}
\hline $\begin{array}{l}\text { Perceptions of the } \\
\text { need for Business } \\
\text { Model change } \\
\end{array}$ & Key Challenges & Community of Practice Needs & $\begin{array}{l}\text { Temporal CoP - } \\
\text { achievements }\end{array}$ \\
\hline Customer Segment & $\begin{array}{l}\text { Getting some commercial } \\
\text { projects started with the } \\
\text { pilot test bed will show the } \\
\text { practicality of this } \\
\text { approach }\end{array}$ & $\begin{array}{l}\text { Need for introductions and access } \\
\text { to the University/Research } \\
\text { Institutions network of } \\
\text { farmers/growers to get some pilot } \\
\text { plants going ... }\end{array}$ & $\begin{array}{l}\text { Working through the business } \\
\text { model workshops has been } \\
\text { critical to identifying the target } \\
\text { customer segments }\end{array}$ \\
\hline \multirow[t]{2}{*}{ Value Proposition } & $\begin{array}{l}\text { Need a full-scale } \\
\text { production plant going to } \\
\text { get the data needed to } \\
\text { identify the key metrics for } \\
\text { different types of } \\
\text { framers/growers }\end{array}$ & $\begin{array}{l}\text { The expertise and resources to } \\
\text { develop the full-sized prototype } \\
\text { are key to the next stage in the } \\
\text { product development }\end{array}$ & $\begin{array}{l}\text { The full nine month } \\
\text { programme will deliver the key } \\
\text { resources and outputs needed to } \\
\text { both show the growth potential } \\
\text { and give further investor input }\end{array}$ \\
\hline & $\begin{array}{l}\text { Access to other Farmers } \\
\text { and Growers willing to } \\
\text { engage and fund a full-pilot } \\
\text { system .. }\end{array}$ & $\begin{array}{l}\text { Constant opportunities to redefine } \\
\text { the business model and re-pitch it } \\
\text { to other investors }\end{array}$ & $\begin{array}{l}\text { Already had significant interest } \\
\text { from other parties willing to } \\
\text { invest and commit resources. }\end{array}$ \\
\hline $\begin{array}{l}\text { Relationship } \\
\text { Management }\end{array}$ & $\begin{array}{l}\text { Needing the Full-pilot } \\
\text { system up and working to } \\
\text { generate the } \\
\text { data/performance metrics } \\
\text { for different crop types ..... }\end{array}$ & $\begin{array}{l}\text { The resources available from the } \\
\text { research institute to gain access to } \\
\text { farms and resources at their } \\
\text { establishment is vital. }\end{array}$ & $\begin{array}{l}\text { The regular meeting with the } \\
\text { tCoP have created a series of } \\
\text { activities and actions for further } \\
\text { work. }\end{array}$ \\
\hline
\end{tabular}

\section{e. Agritech Start-up E}

Enterprise E's product is an entirely new development that will both speed up soil health intelligence, but also bring it down to a level that is both cheap enough and fast enough to be a practical tool for the urban farmer.

Table 11. - Agritech Start-up informal CoP, Strategic Orientation and Business Model Changes (Started and Finished ${ }^{2}$ )

\begin{tabular}{|c|c|c|c|c|}
\hline $\begin{array}{c}\text { Perceptions of the need } \\
\text { for Business Model } \\
\text { change }\end{array}$ & Key Challenges & $\begin{array}{c}\text { Key Business Model } \\
\text { Changes }\end{array}$ & $\begin{array}{c}\text { Change in Values, } \\
\text { Attitudes and } \\
\text { Practices }\end{array}$ & $\begin{array}{c}\text { Expected and } \\
\text { Actual Impact } \\
\text { (Performance } \\
\text { Measure) }\end{array}$ \\
\hline $\begin{array}{l}\text { Enterprise } \mathbf{E} \\
\text { Entrepreneurial Intentions } \\
\text { - Changing agronomists } \\
\text { and farm-managers } \\
\text { approach to managing the } \\
\text { application of fertilizers } \\
\text { and its consequential } \\
\text { harmful run-offs }\end{array}$ & $\begin{array}{c}\text { Changing farm- } \\
\text { managers approach } \\
\text { to evaluating soil } \\
\text { health }^{1}\end{array}$ & $\begin{array}{c}\text { Develop new } \\
\text { markets }^{1} \\
\text { Develop the business } \\
\text { model ROI for the } \\
\text { new soil health } \\
\text { product }^{2}\end{array}$ & Prospector $^{2}$ & $\begin{array}{l}\text { Quick solutions to } \\
\text { market identification } \\
\text { and sales outlets } \\
\text { Development of } \\
\text { fully-field tested } \\
\text { products, and } \\
\text { developed sales tools } \\
\text { for } \\
\text { commercialization } \\
\text { ch }\end{array}$ \\
\hline
\end{tabular}

Key Target Customers - Enterprise E's end users are farmers and growers, future of soil health intelligence - our handheld sensor product provides comprehensive analyses of soil health in-field in 5 minutes, thereby increasing the efficiency and efficacy of land management decision-making of agricultural practitioners. 
Value Propositions - Enterprise E's product will reduce the overuse of chemicals and fertilizers on farms and improve their soil health, which would reduce agricultural run-off, improve food security, and sequester carbon in soil (which will mitigate the impact of greenhouse gas emissions on climate change).

Channels to Market - Companies providing information about the biological indicators of soil health include Solvita, Trace Genomics and Teralytic. Solvita's test can be done on-farm, but it only provides one biological indicator (CO2 emissions) of soil health and so is typically not used on its own for agronomic decision-making. Trace Genomics, using a DNA- based technique, only gives information about the presence of known, specific soil microbes and does not report on their activities in soil, which limits its usefulness to agronomists; furthermore it cannot be used on-farm. Lastly, Teralytic provides a soil health solution that is used on-farm, but it relies on $\mathrm{CO} 2$ emissions as its biological indicator of soil health.

Relationship Management - The enterprise E has a working prototype and is currently working on the AI (Machine learning) side to provide useful information on the biological soil health indicators. Both the sensor and reader products have been extensively field tested, and the next phase is to finalise the data analysis and production of a farm report.

Table 12. - Agritech Start-up informal tCoP, looking at the Front-Stage of the Business Model (Started ${ }^{1}$ and Finished ${ }^{2}$ )

\begin{tabular}{clll}
\hline $\begin{array}{c}\text { Perceptions of the } \\
\text { need for Business } \\
\text { Model change }\end{array}$ & \multicolumn{1}{c}{ Key Challenges } & \multicolumn{1}{c}{$\begin{array}{c}\text { Community of Practice } \\
\text { Needs }\end{array}$} & $\begin{array}{c}\text { Temporal CoP - } \\
\text { achievements }\end{array}$ \\
\hline Customer Segment & $\begin{array}{l}\text { Currently the target } \\
\text { customer segments are } \\
\text { very generic, farmers } \\
\text { and agronomists }\end{array}$ & $\begin{array}{l}\text { Help both finalize the target } \\
\text { specification of the sensor, } \\
\text { reader and final data analyzer }\end{array}$ & $\begin{array}{l}\text { Evaluation of the soil-health } \\
\text { product against its closest } \\
\text { competitors, identifying } \\
\text { strengths and weaknesses. }\end{array}$ \\
\hline Value Proposition & $\begin{array}{l}\text { Converting what is } \\
\text { clearly a product } \\
\text { differentiator into } \\
\text { something that is } \\
\text { appealing to the target } \\
\text { customer }\end{array}$ & $\begin{array}{l}\text { Help with understanding the } \\
\text { attitudes an behaviors of the } \\
\text { target customers to using new } \\
\text { technology }\end{array}$ & $\begin{array}{l}\text { To undertake a market } \\
\text { intelligence and insight } \\
\text { report on the industry } \\
\text { regarding using different } \\
\text { technologies/sensor to } \\
\text { capture soil health. }\end{array}$ \\
\hline Channels & $\begin{array}{l}\text { Understanding how } \\
\text { farmers and agronomists } \\
\text { obtain their soil health } \\
\text { data }\end{array}$ & $\begin{array}{l}\text { Utilization of the CoP's } \\
\text { network and access to } \\
\text { practitioners and advisors } \\
\text { who directly work with } \\
\text { farmers and farmer advisors. }\end{array}$ & $\begin{array}{l}\text { Develop a product launch } \\
\text { plan with realistic timelines } \\
\text { and identification of } \\
\text { actions. }\end{array}$ \\
\hline $\begin{aligned} \text { Relationship } \\
\text { Management }\end{aligned}$ & $\begin{array}{l}\text { Developing a wider } \\
\text { network of } \\
\text { farmers/growers to } \\
\text { better understand the } \\
\text { key challenges that } \\
\text { affect the sustainability } \\
\text { of their farm/crop ... }\end{array}$ & $\begin{array}{l}\text { Utilizing the opportunities to } \\
\text { undertake further } \\
\text { pilot/protyping trials in the } \\
\text { field. }\end{array}$ & $\begin{array}{l}\text { Develop a trial plan that } \\
\text { identifies the critical } \\
\text { product testing essential for } \\
\text { commercializing the } \\
\text { product/service. }\end{array}$ \\
\hline
\end{tabular}

\section{f. UK Agritech Start-up F}

Start-up F believes that the current Agri-food system is essentially broken, inefficient, depletive, and damaging to the environment. They are on a mission to create healthier and more nutrious proteins from plant-based foods using more sustainable crops. 
Table 13. - Agritech Start-up informal CoP, Strategic Orientation and Business Model Changes (Started ${ }^{1}$ and Finished ${ }^{2}$ )

\begin{tabular}{|c|c|c|c|c|}
\hline $\begin{array}{c}\text { Perceptions of the need } \\
\text { for Business Model } \\
\text { change }\end{array}$ & Key Challenges & $\begin{array}{l}\text { Key Business } \\
\text { Model Changes }\end{array}$ & $\begin{array}{c}\text { Change in Values, } \\
\text { Attitudes and } \\
\text { Practices }\end{array}$ & $\begin{array}{l}\text { Expected and } \\
\text { Actual Impact } \\
\text { (Performance } \\
\text { Measure) }\end{array}$ \\
\hline \multirow{2}{*}{$\begin{array}{l}\text { Enterprise } \mathbf{F} \\
\text { Entrepreneurial } \\
\text { Intentions - Change the } \\
\text { nature of use of protein } \\
\text { based plant extracts }\end{array}$} & $\begin{array}{l}\text { Getting these } \\
\text { food start-ups to } \\
\text { adopt the new } \\
\text { plant-based } \\
\text { protein extract }{ }^{1}\end{array}$ & $\begin{array}{l}\text { Develop new } \\
\text { markets and } \\
\text { increase share of } \\
\text { existing protein- } \\
\text { extract market }^{1}\end{array}$ & Analyser ${ }^{1}$ & $\begin{array}{l}\text { Identifying other } \\
\text { opportunities for } \\
\text { own-branded } \\
\text { products e.g. } \\
\text { substitute milk }{ }^{1}\end{array}$ \\
\hline & $\begin{array}{l}\text { Getting Agri-food } \\
\text { production } \\
\text { companies to be } \\
\text { more mindful } \\
\text { about the } \\
\text { processes used to } \\
\text { get this protein } \\
\text { extract }^{2}\end{array}$ & $\begin{array}{c}\text { Develop the } \\
\text { business model } \\
\text { value proposition } \\
\text { that focuses on the } \\
\text { environmental } \\
\text { impact of other } \\
\text { protein extraction } \\
\text { methods }^{2}\end{array}$ & Prospector $^{2}$ & $\begin{array}{c}\text { Become a } \\
\text { knowledge and } \\
\text { expert source for } \\
\text { other food protein } \\
\text { plant extraction } \\
\text { start-ups }^{2}\end{array}$ \\
\hline
\end{tabular}

Key Target Customers - Enterprise F's main customers are Agri-food producers making their own branded plant-based food products (for example: milks, vegan sausages, burgers, etc.) these are large supermarkets, and well-established food companies, food start-ups, and other businesses making food replacement and protein powders. Their customers are the end-users the true consumers of these products.

Value Propositions - Enterprise F's protein extraction focuses on producing a purity product that is mindful of the climate change issues of using substances that are harmful to the planet. The key VP is the novel method that yields protein isolates with adequate purity while exceeding the functionalities of protein obtained using other extraction methods, and thus minimises the use of unnecessary chemicals, water and energy use. The novel process co-yields starch and fibres and thus requirement for minimum purification prior to usage, by their customers, in the production of food products, this both increases overall sustainability and help reduce waste. So the main USP are:

- Better product functionalities - better mouthfeel, chewiness, and texture

- Reduced costs to the Agri-food companies, requiring less ingredients to achieve their functionalities
- $\quad$ Simplest product labels

- Simpler and shorter production processes

- More environmentally friendly proteins requiring less energy, producing very little waste

Channels to Market - The large protein production companies like Dupont and Puris, Burcon Nutrascience, Roquette, Emsland, Cosucra are just some of the main competitors. There are no major protein producers in the UK, and with the advent of BREXIT, this makes it expensive and difficult for Agri-food companies using these protein extracts to source their feedstuff.

Relationship Management - Still at the working prototype level, and therefore need more customers to test our protein extract! However, the development of a pea-protein based milk has allowed the start-up to work with consumers on testing some of the important aspects of attitude and behaviour of consumer purchase this type of protein-based food. The primary research with consumers has helped them improve product taste, appearance, and flavour, as well as exploring different product applications and enabled deeper understanding of the functionalities of their protein extracts for a range of food applications: emulsification's, oil-binding and gelation. 
Table 14. - Agritech Start-up informal tCoP, looking at the Front-Stage of the Business Model (Started ${ }^{1}$ and Finished ${ }^{2}$ )

\begin{tabular}{|c|c|c|c|}
\hline $\begin{array}{l}\text { Perceptions of the } \\
\text { need for Business } \\
\text { Model change } \\
\end{array}$ & Key Challenges & $\begin{array}{c}\text { Community of Practice } \\
\text { Needs }\end{array}$ & $\begin{array}{l}\text { Temporal CoP - } \\
\text { achievements }\end{array}$ \\
\hline Customer Segment & $\begin{array}{l}\text { The next stage is to } \\
\text { develop a full-size } \\
\text { protein manufacturing, } \\
\text { with targeted end- } \\
\text { products to create } \\
\text { revenue streams }\end{array}$ & $\begin{array}{l}\text { Need to recruit certain key } \\
\text { resources - technical manager } \\
\text { with expertise in this field to } \\
\text { help develop/plan and build } \\
\text { the next stage of } \\
\text { commercialization }\end{array}$ & $\begin{array}{l}\text { Access to mentor and } \\
\text { coaching around developing } \\
\text { a person specification for } \\
\text { the TM, and further } \\
\text { network resources. }\end{array}$ \\
\hline \multirow[t]{2}{*}{ Value Proposition } & $\begin{array}{l}\text { To better optimize the } \\
\text { production prototype it } \\
\text { is important to work } \\
\text { with a select group of } \\
\text { food companies to help } \\
\text { test the overall food } \\
\text { concept. }\end{array}$ & $\begin{array}{l}\text { To help develop a strategy to } \\
\text { approach this larger food } \\
\text { producer so that we can carry } \\
\text { this out, without jeopardizing } \\
\text { the loose of IP! }\end{array}$ & $\begin{array}{l}\text { Re-evaluation of the target } \\
\text { markets, providing a market } \\
\text { intelligence and insight } \\
\text { report and further in } \\
\text { curricula projects for the } \\
\text { university's postgrads. }\end{array}$ \\
\hline & $\begin{array}{l}\text { Working with Agri-food } \\
\text { companies has created a } \\
\text { challenge in developing } \\
\text { a viable financial stream } \\
\text { to fund R\&D and } \\
\text { overall business } \\
\text { development. }\end{array}$ & $\begin{array}{l}\text { Understanding of the types of } \\
\text { co-partnerships around doing } \\
\text { collaborative R\&D, but } \\
\text { without giving away their IP! }\end{array}$ & $\begin{array}{l}\text { Improved network of } \\
\text { university/research institute } \\
\text { researchers interested in co- } \\
\text { research opportunities. }\end{array}$ \\
\hline $\begin{array}{l}\text { Relationship } \\
\text { Management }\end{array}$ & $\begin{array}{l}\text { Trying to get Innovate } \\
\text { UK investment requires } \\
\text { greater identification of } \\
\text { the traction and } \\
\text { validation of the } \\
\text { process/product in the } \\
\text { marketplace..... }\end{array}$ & $\begin{array}{l}\text { Working with the Shake } \\
\text { Programme will help the } \\
\text { business develop this .... And } \\
\text { then be more successful of } \\
\text { gaining R\&D grants! }\end{array}$ & $\begin{array}{l}\text { Improved skills on } \\
\text { developing and being } \\
\text { successful with future bids. }\end{array}$ \\
\hline
\end{tabular}

\section{There are several significant knowledge/expertise outcomes for the six UK start-ups when engaging with the informal CoP:}

- $\quad$ Soon after starting the process of support from the Climate Change Initiative Programme, these enterprises entered into a informal CoP focused on the specific areas of support/expertise needed and developing their business models.

- They are both having regular monthly meetings of the tCoP are conducted at the university (which engage in the program) and remotely via Microsoft Teams.

- The programme is highly structured to deliver several key outputs, a market evaluation report, identified skills and competence needs, and a programme of workshops delivering skills training in both technical and business toolkits. This is repeated for all the six cases.

Observing each start-up, with the support from the informal CoP, Enterprise A have received a frequent Production and Processing expertise (in life sciences), when enterprise $\mathrm{B}$ is keen to further diversify its product/services to other market opportunities. At the time of surveyed - about a year after each start-up begin their operations, Enterprise $\mathrm{C}$ and $\mathrm{D}$ are both anticipated to have a realistic product launch strategy. Start-up E is expecting to have its full plans finalised for a product launch in 2023, and start-up F will launch at least two other products. As they are both new in the market, they expect to have more support from the CoP not only in technology knowledge transfer but also continue to penetrate and develop their potential markets.

\subsection{Vietnamese Agritech Start-ups}

\section{a. Agritech Start-up G}

Vietnam's agricultural product market currently faces many problems such as the excessive use of plant protection products, pesticides,..causing harm to consumers. Start-up G was established in 2016 with the mission to produce fresh vegetables in following the strict national and international production standards and process. 
Table 15. - Agritech Start-up informal CoP, Strategic Orientation and Business Model Changes

\begin{tabular}{|c|c|c|c|c|}
\hline $\begin{array}{c}\text { Perceptions of the need } \\
\text { for Business Model } \\
\text { change }\end{array}$ & Key Challenges & $\begin{array}{l}\text { Key Business } \\
\text { Model Changes }\end{array}$ & $\begin{array}{c}\text { Change in Values, } \\
\text { Attitudes and } \\
\text { Practices }\end{array}$ & $\begin{array}{c}\text { Expected and } \\
\text { Actual Impact } \\
\text { (Performance } \\
\text { Measure) } \\
\end{array}$ \\
\hline \multirow{2}{*}{$\begin{array}{r}\text { Enterprise G } \\
\text { Entrepreneurial } \\
\text { Intentions - Changing } \\
\text { production methods and } \\
\text { processes to meet } \\
\text { consumption needs and } \\
\text { market conditions }\end{array}$} & $\begin{array}{l}\text { Apply high } \\
\text { technology in the } \\
\text { field of fresh } \\
\text { vegetable } \\
\text { production }\end{array}$ & $\begin{array}{l}\text { Develop new } \\
\text { markets, targeting a } \\
\text { group of middle- } \\
\text { class customers } \\
\text { who want to use } \\
\text { fresh products }\end{array}$ & Analyser & $\begin{array}{l}\text { Development of } \\
\text { fully-field tested } \\
\text { products, and } \\
\text { developed sales } \\
\text { channels for } \\
\text { commercialization }\end{array}$ \\
\hline & $\begin{array}{l}\text { Problems of } \\
\text { supply chain } \\
\text { disruption and } \\
\text { increase in input } \\
\text { prices due to } \\
\text { covid-19 }\end{array}$ & $\begin{array}{l}\text { Try to save costs } \\
\text { and apply } \\
\text { technological } \\
\text { improvements to } \\
\text { increase labor } \\
\text { productivity }\end{array}$ & Prospector & $\begin{array}{l}\text { Become an expert } \\
\text { in applying } \\
\text { hydroponics and } \\
\text { automatic } \\
\text { environment } \\
\text { control system }\end{array}$ \\
\hline
\end{tabular}

Key Target Customers - The company's main customers are individuals and households who want to use fresh and clean agricultural products in Hochiminh city. Previously, there was also a group of high-class restaurants and hotels (Novotel, Rex, Renaissance, Sheraton, Saigon Prince..), but due to covid-19 pandemic, they had to be closed, which a part affected to the company's business orientation. This situation leads the company focusing more on groups of middle-class individuals and households.

Value Propositions - The company commits to produce fresh vegetables with 3 NO criteria: no pesticides, no growth drugs, and no preservatives. To do that, the company have strictly followed the provisions of the Global G.A.P and ISO 22000:2005 standards. Their products have gone through 5 CLEAN processes: clean seeds, clean planting process, clean harvesting, clean packaging, and clean transportation.

Channels to Market - The company uses indirect distribution channels to sell to large supermarkets in Hochiminh city (such as Coopmart, Nam An..) and builds its own sales system with partners in residential areas. The company also conducts direct sales of products through receiving online orders (in designing certain types of fruit and vegetable combos) on the company's website.

Relationship Management - The company realizes that there are still many shortcomings in customer care, as they did not really pay attention to valueadded services for customers. In the coming time, the company will make efforts to find solutions to improve the relationship with customers.

Table 16. - Agritech Start-up informal tCoP, looking at the Front-Stage of the Business Model

\begin{tabular}{clll}
$\begin{array}{c}\text { Perceptions of the } \\
\text { need for Business } \\
\text { Model change }\end{array}$ & \multicolumn{1}{c}{ Key Challenges } & \multicolumn{1}{c}{$\begin{array}{c}\text { Community of Practice } \\
\text { Needs }\end{array}$} & $\begin{array}{c}\text { Temporal CoP - } \\
\text { achievements }\end{array}$ \\
\hline Customer Segment & $\begin{array}{l}\text { Due to covid-19, high- } \\
\text { end hotels and } \\
\text { restaurants had to close, } \\
\text { the company lost a main } \\
\text { number of traditional } \\
\text { customers and have to } \\
\text { focus more on } \\
\text { individual and } \\
\text { household customer } \\
\text { segments. }\end{array}$ & $\begin{array}{l}\text { Need help with methods and } \\
\text { network to reach as many } \\
\text { customers as possible }\end{array}$ & $\begin{array}{l}\text { Through tCoPs (such as } \\
\text { social networks) increase } \\
\text { the company's reputation } \\
\text { and expand the customer } \\
\text { network, expand the market }\end{array}$ \\
\hline Value Proposition & $\begin{array}{l}\text { With high competition } \\
\text { in the market of fresh } \\
\text { vegetables, and with } \\
\text { high materials prices, to } \\
\text { keep the best product } \\
\text { quality and reduce } \\
\text { selling price to attract } \\
\text { more customers is a big }\end{array}$ & $\begin{array}{l}\text { Knowledge and experience } \\
\text { support to improve } \\
\text { technology, improve } \\
\text { productivity while } \\
\text { maintaining good product } \\
\text { quality and reducing costs }\end{array}$ & $\begin{array}{l}\text { The company has received } \\
\text { consultation from } \\
\text { universities' researchers and } \\
\text { tCoPs and has invested in } \\
\text { improving production } \\
\text { technology and } \\
\text { productivity, thus revenue } \\
\text { has grown well }\end{array}$ \\
\hline
\end{tabular}


challenge for the company.

\begin{tabular}{clll}
\hline Channels & $\begin{array}{l}\text { High logistics costs for } \\
\text { indirect distribution } \\
\text { channels and difficulties } \\
\text { in controlling sales } \\
\text { partners can affect the } \\
\text { company's } \\
\text { competitiveness and } \\
\text { brand }\end{array}$ & $\begin{array}{l}\text { Seeking for types of co- } \\
\text { partnerships around }\end{array}$ & $\begin{array}{l}\text { Suppliers and customers } \\
\text { networks expansion }\end{array}$ \\
Relationship & $\begin{array}{l}\text { The company is still } \\
\text { Management }\end{array}$ & $\begin{array}{l}\text { Improve customer care skill } \\
\text { employees, thus the } \\
\text { customers relationship is } \\
\text { still not well performed }\end{array}$ & \\
\hline
\end{tabular}

\section{b. Agritech Start-up H}

Start-up H was established in 2015, specializing in providing products and services for the seafood industry. Start-up $\mathrm{H}$ stablished its vision and mission towards organic agriculture, using the very natural sources of raw materials to create the highest quality and safest products. Farm 3T's farming areas feed fish entirely with high-quality floating pellets. With a team of qualified and experienced technicians, the management of the farming environment and disease prevention for fish are carried out periodically and strictly in accordance with the standard process.

Table 17. - Agritech Start-up informal CoP, Strategic Orientation and Business Model Changes

\begin{tabular}{|c|c|c|c|c|}
\hline $\begin{array}{c}\text { Perceptions of the need } \\
\text { for Business Model } \\
\text { change }\end{array}$ & Key Challenges & $\begin{array}{l}\text { Key Business } \\
\text { Model Changes }\end{array}$ & $\begin{array}{c}\text { Change in Values, } \\
\text { Attitudes and } \\
\text { Practices }\end{array}$ & $\begin{array}{c}\text { Expected and } \\
\text { Actual Impact } \\
\text { (Performance } \\
\text { Measure) } \\
\end{array}$ \\
\hline $\begin{array}{r}\text { Entrepreneurial } \\
\text { Intentions - Changing } \\
\text { production methods and } \\
\text { processes to ensure } \\
\text { stable and quality } \\
\text { supply, to meet } \\
\text { consumption needs and } \\
\text { market conditions }\end{array}$ & $\begin{array}{l}\text { Problems of } \\
\text { supply chain } \\
\text { disruption and } \\
\text { increase in input } \\
\text { prices due to } \\
\text { covid-19 }\end{array}$ & $\begin{array}{l}\text { Develop supply, } \\
\text { improve } \\
\text { distribution system, } \\
\text { and attract new } \\
\text { customers. Try to } \\
\text { reduce costs and } \\
\text { apply technological } \\
\text { improvements to } \\
\text { increase labor } \\
\text { productivity and } \\
\text { product quality }\end{array}$ & Prospector & $\begin{array}{c}\text { Improve } \\
\text { production process } \\
\text { and technology; } \\
\text { develop sales } \\
\text { channels for distant } \\
\text { market. }\end{array}$ \\
\hline
\end{tabular}

Key Target Customers: The company's main customers are classified into two groups: (1) Clean food stores and schools; (2) Individuals who are intellectuals, interested in healthcare and/or customers with higher income than average level, knowledgeable about clean food agriculture. Most of their company's targeted customers are located at Northern provinces of Vietnam. A high percentage of customers are Hanoi residents.

Value Propositions: The company embraces business philosophy of "clean from farm to table". All products are grown to organic or Global G.A.P standards, strictly selected, processed, checked, and have their origins traced all the way. Many products are highly unique because they are grown according to their own process on the farm, which is highly appreciated by most of the customers. The company commits to ensuring "Five NO" criteria, which are no weight gainers, no heavy metals, no chemicals, no antibiotics, and no preservatives. The adoption of cutting-edge technology for cage fish farming or allfemale shrimp aquaculture developed by Enzootic have helped the company build customers' trust and loyalty.

Channels to Market: The company is proactive in finding and distributing products to partners and customers. The company established both direct and indirect channels of distribution, yet indirect channel acts as the main one. Since the Covid-19 outbreak, online sales activities have been strongly promoted and initially shown positive results.

Relationship Management: The company is highly appreciated by many customers. The customer loyalty rate is $50-70$, which is quite a positive 
number compared to other competitors in the food service industry. Customer care service has performed effectively which requires the company to promote when production on the farm reaches a higher scale.

Table 18. - Agritech Start-up informal tCoP, looking at the Front-Stage of the Business Model

\begin{tabular}{|c|c|c|c|}
\hline $\begin{array}{l}\text { Perceptions of the } \\
\text { need for Business } \\
\text { Model change }\end{array}$ & Key Challenges & $\begin{array}{c}\text { Community of Practice } \\
\text { Needs }\end{array}$ & $\begin{array}{l}\text { Temporal CoP - } \\
\text { achievements }\end{array}$ \\
\hline \multirow[t]{3}{*}{ Customer Segment } & $\begin{array}{l}\text { Schools, important } \\
\text { partners had to close due } \\
\text { to Covid-19. The } \\
\text { company also face with } \\
\text { high competition in this } \\
\text { segment. }\end{array}$ & $\begin{array}{l}\text { Need help with methods and } \\
\text { network to reach as many } \\
\text { customers as possible }\end{array}$ & \multirow[t]{3}{*}{$\begin{array}{l}\text { Through CoPs (such as } \\
\text { social networks) increase } \\
\text { the company's reputation } \\
\text { and expand the customer } \\
\text { network, expand the market }\end{array}$} \\
\hline & $\begin{array}{l}\text { Grocery stores often put } \\
\text { the issue of profit and } \\
\text { food preservation first, } \\
\text { so they are easy to } \\
\text { change supply partners } \\
\text { when they find it more } \\
\text { profitable. }\end{array}$ & & \\
\hline & $\begin{array}{l}\text { Relatively stable retail } \\
\text { customers. }\end{array}$ & & \\
\hline \multirow[t]{4}{*}{ Value Proposition } & $\begin{array}{l}\text { The biggest challenge is } \\
\text { how to ensure a stable } \\
\text { and quality supply } \\
\text { because the company's } \\
\text { financial incapability } \\
\text { and the risky nature of } \\
\text { farming. }\end{array}$ & $\begin{array}{l}\text { Knowledge and experience } \\
\text { support to improve } \\
\text { technology, improve } \\
\text { productivity while } \\
\text { maintaining good product } \\
\text { quality and reducing costs }\end{array}$ & \multirow[t]{2}{*}{$\begin{array}{l}\text { The company has received } \\
\text { consultation from } \\
\text { universities' researchers and } \\
\text { tCoPs and has invested in } \\
\text { improving production } \\
\text { technology and } \\
\text { productivity, thus revenue } \\
\text { has grown well }\end{array}$} \\
\hline & $\begin{array}{l}\text { The production cost still } \\
\text { high compared to the } \\
\text { products in the } \\
\text { traditional market. }\end{array}$ & & \\
\hline & $\begin{array}{l}\text { Shrimp and fish are } \\
\text { fresh, heavy and bulky } \\
\text { products, so the 3rd } \\
\text { shippers are often not } \\
\text { excited to receive the } \\
\text { goods. Especially during } \\
\text { the epidemic, many } \\
\text { shipping companies } \\
\text { refused to ship the } \\
\text { farm's goods. }\end{array}$ & $\begin{array}{l}\text { Seeking for types of co- } \\
\text { partnerships around doing } \\
\text { collaborative R\&D }\end{array}$ & $\begin{array}{l}\text { Improved network of } \\
\text { university/research institute } \\
\text { researchers interested in co- } \\
\text { research opportunities. }\end{array}$ \\
\hline & $\begin{array}{l}\text { Distributing fresh } \\
\text { shrimp, crabs and fish } \\
\text { directly from the farm to } \\
\text { the big agency stores } \\
\text { faces many difficulties } \\
\text { because of the high } \\
\text { operating costs, and the } \\
\text { preservation in Hanoi } \\
\text { has not been efficient. }\end{array}$ & & \\
\hline $\begin{array}{l}\text { Relationship } \\
\text { Management }\end{array}$ & $\begin{array}{l}\text { Marketing and product } \\
\text { introduction is still } \\
\text { limited. Customer care } \\
\text { service has not been } \\
\text { professional enough } \\
\text { because customer } \\
\text { service staff are not well } \\
\text { trained or lack } \\
\text { motivation to work } \\
\text { effectively. }\end{array}$ & $\begin{array}{l}\text { Improve customer care skills } \\
\text { to be more professional }\end{array}$ & Not yet \\
\hline
\end{tabular}




\section{There are several significant knowledge/expertise outcomes for the two Vietnamese businesses engaging with experts in this Agri-tech community:}

Enterprise $\mathrm{G}$ has received important supports from the tCoPs during a quite long period of 5 years' operation from the beginning until now:

- Regular meetings are conducted with the universities specialized in science and agriculture (University of Agroforestry, HUTECH, Can Tho University..) to exchange knowledge of applying high-tech to agriculture production. Invite researchers, lecturers and students participating in the company's R\&D activities and technology transfer projects. Internal trainings have been frequently updated to the company's staff.

- Joining social networks (Agritech network, Fresh vegetables production network, Gardening network, Fresh agriculture network..)

The enterprise expects in the short term to conduct knowledge and experience exchange activities on a regular and continuous basis to enhance the development of all the joined parties. In the longer term, these CoPs should be developed in a more selective way with the participants to minimize those who may affects to the goals and development of the $\mathrm{CoP}$

With enterprise $\mathrm{H}$, they have:

- Participated in business community network and several business forums for exchange of practices, experiences and tools. However, the role of universities and research institutes is still limited in those groups.

- Contacted with scientist in agricultural field, technological experts and economists for consultation related to cultivation, production process and measures to adapt to changes of business environment.

The company expects that the participants in communities of practice learn together by focusing on problems that are directly related to their work. In the short term, this made their work easier or more effective; in the long term, it helped build both their communities and their shared practices - thus developing capabilities critical to the continuing success of the companies.

\section{CONCLUSIONS, IMPLICATIONS, AND LIMITATIONS}

Even before the onset of the Global Pandemic, Covid-19, governments have been concerned about issues of long-term productivity growth in the SME sector (Isabelle Roland, 2018). In the UK, the industrial strategy main goals launched in 2018 were targeted at higher growth potential SME's, helping prioritise future financial and management support, since these are two of the main obstacles most often identified in SME research (Goldman Sachs, 2015; Isabelle Roland, 2018). In Vietnam, in addition to the government policies of reducing taxes and removing administrative procedures, agencies such as the Department of Industry and Trade, the Department of Agriculture and Rural Development have supported agribusiness enterprises helping promote domestic product consumption and exportation. Many informal groups in the form of tCoPs have created connections for these enterprises to help find new outlets for their products.

This study on agritech startups in the UK and Vietnam, using tCoPs to enhance business growth, has illustrated the very real difficulties of startup knowledge exchange on specific knowledge, expertise and technology. Importantly these startups and scale-up businesses embrace two key challenges: the development of a new agri-tech product/service which ultimately requires changes to their own business in the form of new skills for their people, new processes and technology to create, develop and deliver these solutions to their targeted customers segments (Deloitte, 2020). The digital transformation underlying their agri-tech new products/services require them building to build digital capabilities, integrating new digital talent (inside and outside their business), and lastly developing their employees' digital skillsets. Our research study has focused on three areas where the temporal Community of Practice approach has delivered real value:

- Identifying knowledge/expertise gaps based on their current/future technological needs, helping identify the skills needs to grow and sustain the business.

- Update internal training - based on the acquired technology and methods of construction obtained through the tCoP. The tCoP has helped the businesses identify the training needs and the means of deliver on this to maintain their learning.

- Connect businesses - based on the network of participants (Community members), helped to promote the relationship between the founders/managers and these external resources, providing the environment for sharing, discussing, exchange knowledge and experiences, developing customers network and enhancing growth.

Our findings show that these Agri-tech enterprises generally start out with a prospector strategy, one based on a technology readiness model, developing their initial product/service, and then looking to growing its market penetration, securing sustainable revenue/profit streams and allowing for more investment in their R\&D. Some startups will then adopt a more conservative position - either attempting to defend its current marketplace, or others who react to changes in marketplace - 
sometimes too late. Other Agri-tech startups instead take a more active role, some analyzing the marketplace dynamics carefully and changing their strategies, first defensive, and then prospective, carefully weighing up the benefits and costs of any change; prospectors take a more aggressive and proactive stance, continuously searching for new opportunities and ways of challenging the status quo.

The business change model framework, and its corresponding Osterwalder Business Model Canvas toolset, helped all enterprises understand the important link between environmental threats and opportunities, their sensemaking of the potential changes needed in their business model, and the practical issues of then implementing these changes with the helped from the tCoP. Yet successful collaboration is largely down to the individuals involved having an investment in the success of the overall Communities of Practice (tCoP). To better understand the challenges and issues likely to affect the success or otherwise of the partnership, the researchers undertook a careful evaluation of the business entrepreneurs' motivations and expectations of the informal tCoP, and its impact on their business model.

The other contribution of this research study is its original insights into Agri-tech entrepreneurship. The opportunities for resource acquisition and further collaboration have been reported throughout the findings, this study also adds original materials and insights into how the use of these temporal Communities of Practice is organised. The tCoP's formation is both a temporal and permanent solution for effective collaboration and start-up growth development. The case study of eight entrepreneurial start-ups in both UK and Vietnam illustrates the huge benefits they experience whilst benefitting from the large pool of resources, expertise and advise open to them.

The different between the benefits received from the CoPs of UK start-ups and Vietnamese start-ups is that, with $6 \mathrm{UK}$ cases, as they are just start their operations for less than one year and receiving support in launching products and penetrating the market, while Vietnamese startups have these kinds of support a few years ago and now receiving benefits in increasing connectivity, expanding network, changing their business model to meet market demand and transition. 6 UK cases only take advantage of support from one $\mathrm{CoP}$ engaged with the university (but still informal), while the 2 Vietnamese cases have joined many different CoPs, including those from social networking channels.

The limitations of this case study are firstly that the data was collected from just eight businesses (6 start-ups in UK which both participated in one govermental funding program and only 2 cases from Vietnam) to both help the start-ups understand what they had benefits from the tCoPs and their expectations. The second limitation was on the depth and detail of each of four front-stage components of the business model. It is possible and desirable to break these down further, and future research might want to consider this to create further measures, however the aim of this research was to quickly assess the areas of strengths and weaknesses within the business and identify those aspects of the ecosystem/CoP that could deliver value.

Finally, policy makers and other practitioners looking to develop and build these types of interventions may want to take our insights into the fundamental actors, relations, and value exchanges within these temporal Communities of Practice. Businesses in not only Agritech sector but also in other fields can also better understand the value and potential of COPs and they can have the right approach and use.

\section{REFERENCES}

[1] Adams, E., \& Freeman, C. (2000). Communities of Practice: bridgig technoogy and knowledge assessment. Journal of Knowledge Management, 4(1), 38-44.

[2] AgFunder Network Partners. (2020). AgriFoodTech in Europe boomed in 2019, with funding up $70 \%$ Year on Year. What's in store for 2020. 2. Retrieved from https://agfundernews.com/agri-foodtech-ineurope-boomed-in-2019-with-funding-up-70yoy-whats-in-store-for-2020.html

[3] Aragon-Sanchez, A., \& Sanchez-Maron, G. (2005). Strategic Orientation, Management Characteristics, and Performance: A Study of Spanish SMEs. Journal of Small Business Management, 43(3), 287-308. Retrieved from http://search.ebscohost.com/login.aspx?direct=tr ue\&db=bth\&AN=17198618\&site=ehost-live

[4] BERR. (2010). SMEs in a Low Carbon Economy. Retrieved from www.berr.gov.uk/files/file49761.doc

[5] Cockburn, I. M., \& Henderson, R. M. (1998). Absorptive Capacity, Coauthoring Behavior, and the Organization of Research in Drug Discovery. The Journal of Industrial Economics, 46(2), 157-182. Retrieved from http://links.jstor.org/sici?sici=0022$1821 \% 28199806 \% 2946 \% 3 \mathrm{~A} 2 \% 3 \mathrm{C} 157 \% 3 \mathrm{AAC}$ CBAT\%3E2.0.CO\%3B2-Q

[6] Cohen, D., \& Prusak, L. (2001). In good company : how social capital makes organizations work. Boston, Mass. ; [Great Britain]: Harvard Business School.

[7] Cross, R., \& Parker, A. (2004). The Hidden Power of Social Networks: understanding how work really gets done in organizations. Boston, MA: Harvard Business School Press. 
[8] De-Graft Johnson Dei, \& Walt, T. B. v. d. (2020). Knowledge Management practices in UniversitiesL The role of communities of practice. Social Science \& Humanities Open, 2(1), 15 .

[9] Deloitte. (2020). A Whole New Ball Game: Navigating digital change in the sports industry. $8 . \quad$ Retrieved from https://www2.deloitte.com/content/dam/Deloitte /global/Documents/Technology-Media-

Telecommunications/gx-digital-transformationsports.pdf

[10]Department for Business Energy \& Industrial Strategy. (2019). 2017 UK GreenHouse Gas Emissions, Final Figures(pp. 46). Retrieved from

https://assets.publishing.service.gov.uk/govern ment/uploads/system/uploads/attachment_data/f ile/776083/2017_Final_emissions_statistics_one _page summary.pdf

[11]Garavan, T. N., Carbery, R., \& Murphy, E. (2007). Managing intentionally created communities of practice for knowledge sourcing across organisational boundaries. The Learning Organization: The International Journal of Knowledge and Oragnizational Learning, 14(1), 34-49.

[12]Glaser, D. A., \& Strauss, A. (1967). The Discovery of Grounded Theory: Strategies for Qualitative Research. New York, NY: Aldine.

[13]Goldman Sachs. (2015). Unlocking UK Productivity: Internationalisation and Innovation in SMEs. 52. Retrieved from http://www.enterpriseresearch.ac.uk/unlockinguk-productivity-internationalisation-andinnovation-of-smes/

[14]Great Britain \& Northern Ireland. (2021). Agritech Sector. 1. Retrieved from https://www.great.gov.uk/international/content/ about-uk/industries/agriculturaltechnology/?_gl=1*1sne02r*_ga*MTc1NzEzN TgwNC4xNjI0NTI4MDY5*_ga 6H60RML3P L*MTYyNDUyODA2OS4xLjAuMTYyNDUy ODA3Ny4w

[15]Greiner, L. E. (1998). Evolution and Revolution as Organizations Grow. Harvard Business Review, May-June, 55-65.

[16]Innovate UK. (2021). Agri-Tech Centres. 1. Retrieved from https://www.agritechcentres.com/contact

[17]Isabelle Roland. (2018). Unlocking SME productivity: review of recent evidence and implications for the UK's industrial strategy (pp. 25). Retrieved from http://cep.lse.ac.uk/pubs/download/is05.pdf

[18]Kang, K. H., \& Kang, J. (2009). HOW DO FIRMS SOURCE EXTERNAL KNOWLEDGE FOR INNOVATION? ANALYSING
EFFECTS OF DIFFERENT KNOWLEDGE SOURCING METHODS. International Journal of Innovation Management, 13(1), 1-17. Retrieved from http://search.ebscohost.com/login.aspx?direct=tr

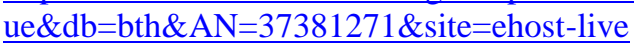

[19]Lara Carminati. (2018). Generalizability in Qualitative Research: a tale of two traditions. Qualitative Health Research, 28(13), 7. Retrieved from https://journals.sagepub.com/doi/10.1177/10497 $\underline{32318788379}$

[20]Mark Saunders, Lewis, P., \& Thornhill, A. (2019). Chapter 4: Understanding research philosophy and approaches to theory development. 47. Retrieved from https://www.researchgate.net/publication/33076 0964_Research_Methods_for_Business_Student s_Chapter 4 Understanding research_philosop hy and approaches to theory development

[21]Miles, R. E., \& Snow, C. C. (1978). Organizational Strategy, Structure and Process. New York: McGraw-Hill.

[22]Nnamdi O. Madichie, Bolat, E., \& Taura, N. (2021). Digital transformation in Wets Africa: a two country, two sector analysis. Journal of Enterprising Communities: People and Places in the Global Economy, 15(2), 15.

[23]Osterwalder, A., Pigneur, Y., Smith, A., \& Etiemble, F. (2020). The Invincible Company. Hoboken, New Jersey, USA: John Wiley \& Sons.

[24]Peter Clough, \& Nutbrown, C. (2012). A Student's Guide to Methodology. London, UK.: Sage Publications Ltd.

[25]Probst, G., \& Borzillo, S. (2008). Why communities of practice succeed and why they fail. European Management Journal, 26(5), 335-347. Retrieved from http://www.sciencedirect.com/science/article/B6 V9T-4SWP24X1/2/dbb451298682776766f494b7e25154e6

[26]Robert K. Yin. (2018). Case Study Research and Applications: Design and Methods. 54. Retrieved from https://www.sagepub.com/sites/default/files/yin 6e chapter_1_getting started.pdf

[27]Seufert, A., Krogh, G. v., \& Bach, A. (1999). Towards Knowledge Networking. Journal of Knowledge Management, 3(3), 180-190.

[28]Van Baalen, P., Bloemhof-Ruwaard, J., \& van Heck, E. (2005). Knowledge Sharing in an Emerging Network of Practice:: The Role of a Knowledge Portal. European Management Journal, 23(3), 300-314. Retrieved from http://www.sciencedirect.com/science/article/B6 V9T-4GCMF1T9/2/516959cddc4 $1 \mathrm{fb} 7 \mathrm{~b} 401 \mathrm{~d} 31 \mathrm{~b} 100 \mathrm{bdddc} 0$ 